\title{
Measuring Family Poverty Quality in Perspective Religion: Case Studies the Poor Population in Southeast Sulawesi.
}

\author{
Hasan Aedy \\ Faculty of Economics, Halu Oleo University. Kendari, Southeast Sulawesi, Indonesia.
}

\begin{abstract}
Poverty is a bad phenomenon that afflicts humans. This is not only caused by physical and economic aspects, but also caused by socio-cultural factors, political, ideological, social, mental attitudes and philosophies of life. Because of poverty and all the problem becomes complicated, complex and with the severity and many variety. This study raised question of how to measure poverty quality of poor families who not quantitative (physical) but qualitative (psychological). This study aims are: (1) to know poverty severity of poor families from qualitative aspects (mental attitude/character, life philosophy and practice of religion that believed in each), (2) to classify poverty level quality achieved by poor, according with results of each measurement, (3), to know form of empowerment that must be done to poor families based on severity of family poverty (from quality aspect). To achieve these objectives, this study uses data collection method of in-depth interviews. Validity data test is done by triangulation, both sources, time and techniques triangulation. Research results showed that poor families in this area consist of three groups: (1) Poor families group with good quality (safe) who look poor but not poor psychologically. They have a good mental attitude with commendable morals. They have good relations with fellow human beings and their social environment. They behave in a simple economy (not stingy and not wasteful). They are harmony with God Almighty. (2) Poor families group with low quality (not secure) to those who are physically look poor, as well as a psychic has fundamental flaws. They have characteristics: relationship to Almighty God is not suitable with laws. They also have wasteful behaviors as smoking and relationships with fellow human beings often bad. (3) Poor families group with lowest quality (least safe) have poor physical and psychological, with characteristics as: relationship with God is not harmonious, relationship with human and social environment, including family and outside environment (society) often disturbed, and the most severe for this group is a life philosophy that only think for short time (instant) so that rules of life can easily be violated in the form of drunkenness, and other immoral behavior (stealing, robbing. commit armed robbery, prostitution for women, and so on). This poor people is most dangerous and their empowerment should be prioritized, both empowerment of mental/moral, spiritual, and economic (life skills).
\end{abstract}

Keywords: Quality poverty, psychological (mental and spiritual)

\section{Introduction}

Poverty phenomenon has been going on since long time. Although government and non-government agencies have attempted in various ways to handle it, but the results have not been able to reduce poverty significantly. With per capita income size of $\$ 2$ per day, number of poor people in world today is estimated at 2.8 billion people. Therefore, poverty is still become population development issue in many countries, especially in developing country as Indonesia (Southeast Sulawesi)

This study examines poverty, not only from quantity aspect as it has been learned and neither strived, nor just physical aspect, but this study examines poor quality aspect, especially quality of mental and spiritual (psychic) which is owned by the poor. The reason is poverty not just a physical phenomenon, such as low production, low incomes, poor nutrition, bad housing and bad environment, but poverty also involves psychological aspects (mentally, behavioral and spiritual weak). Poverty largely a result of main indicators weakness of bad mental psychic as lazy, pessimistic, frustration and lack of a view of life that is wrong and contradicts with productivity of human development.

On other hand, poverty is God objective, which will always exist in human life according with quantity and quality vary from age to age. Therefore, this study attempts to measure life quality of poor families, especially from aspect of psychological (mental - spiritual) of each family head in managing poverty they experienced. This study measured quality factor, not only static quality but also quality dynamic quality. This means the quality has wide impact to poor family's lives, even for society. Knowing life quality of poor families will also know how their empowerment and who is most priority to be empowered, as well as how best to empower them. This is one of urgency that becomes output from this research. 
Poor population data at Southeast Sulawesi until 2012 was 316300 people or about 13.30 percent of population in this area (BPS 2012). They are a poor family with a livelihood of: fishing and traditional farmers, construction workers, port workers, scavengers, physical and metal deformity, elderly people without family, working odd jobs, unemployment, illegal parking attendants, beggars, and so on. Main problem of this study were: (1) how to measure life quality of poor families from psychological aspects (mental attitudes, morals played and religion implementation), (2) how to classify poor families according with their life quality, and (3) how to empower poor families according with high and low life quality of each group.

This study aims is to determine life quality of poor families. The components are not just physical aspect but also mental aspect (mental and spiritual). Therefore, this study is expected able to measure life quality of poor families in area of Southeast Sulawesi. In addition, this study is also expected to find a grouping of poor families according with their life quality, with an effective empowerment, in accordance with quality level of their poverty. Contribution of this study is to determine level of life quality for poor aspects qualitatively that become an integral part of poverty. This study determine best model of empowerment for poor families in accordance with the characteristics of mental attitude and spiritual treatment that they applied.

The theoretical contribution of this study is to enrich of poverty quality that has been found by the experts. Finally, this study focuses on life quality of poor families in measurement of psychological aspects (mental attitudes and behaviors in the moral and spiritual behavior played) the family quality in managing poverty. The study quality is obedience to God Almighty, the internal social relations in family, the neighbors and community at large, the risk of social or social disadvantage experienced by family and others as a result of poverty. This study focuses on these aspects. The results of study will be able to achieve the goals with wideranging implications for empowerment that most effective and most efficient.

\subsection{Philosophical Poverty}

\section{Literature Review}

World with the entire phenomenon is created in pairs. There are earth and sky, day and night, moon and stars, as natural phenomena. There is also a social phenomenon of poverty and well-being, success and failure, wealth and poverty and so on. What secrets are hidden in such circumstances, it is definitely not something harsh or $\neg$ worth it. Everything has the wisdom and virtue to mankind all over the world. One problem that is not desired by people in general is poverty. Poor means insufficiency in science, power or treasure. Therefore, there is poor of science, power and possessions. If all three are owned by someone, then complete the poverty. But in universe, generally Lord has provided sustenance for man to continue his life. These symptoms not only occur in human beings, but also to other creatures.

Life potential for life is a gift from God that should be understood by humans, and life itself is a natural phenomenon related to social phenomena in all lines through which human beings. One of many lines that go through a human life is poverty line. Many humans are at poverty line, even below poverty line. Poor of science, treasure and power are interrelated triad. It may be poor property is a result of poor science or poor power. And in turn, science poor are a result of poor property characteristics and power poor (power of thought). To reduce poverty first investigation should be conducted accurately, or check directly in the field about what the causes or roots of poverty that afflict humans. According with peer review of experts in history of poverty, Hasan Aedy (2007) encapsulates at least five different views, namely:

\section{Functional view}

This view comes from evolution theory which states that primary cause of underdevelopment is custom or tradition (traditionalism). Human occupy key positions in case of underdevelopment or poverty. Although this view comes from F. Hegel, but most famous figures that developing this view is Comte (1798-1857), a famous sociologist from French nationality who suggest a recipe to change ways of thinking at traditional society. Therefore, it required change agent to perform social engineering as accurately as possible.

\section{Modernism view}

This view stems from functional thinking. According with sociological jargon is known as the modernization paradigm. According with this view backwardness or poverty was due to non-functioning of internal components. It is due to human ignorance, low levels of education, poor culture and poor quality of health. According with this view people they are cause of poverty, not because of external factors. Because recipe to handle it is to improve bad conditions they experienced, by improving quality of human resources through education and proper counseling with an introduction to progress of outside world, so they are not confined by ignorance. Mc Lelland, with psychological view, looks poverty as a factor that very individual. Poor is inability to realize the spirit of self-employed individuals in which there is, or may be individual in question does not have the entrepreneurial spirit, so that he is poor.

\section{Optimistic view}

This view is optimistic viewpoint to see the world as a field of struggle and fight to improve fate. This view holds that poverty is not destiny, because poverty can be addressed and alleviated from earth. The 
important thing is to know exactly, what is the background of poverty. Is not the struggle of human life there is a close relationship with each other "even though that relationship may be beneficial or detrimental. Therefore poverty caused due to human error, both individually and collectively can definitely alleviated, by the way correct any errors. This is an optimistic view that is willing to sacrifice the mind, any number of resources and funding, to improve the condition of people are trapped in poverty. The view is what drives many countries of world to eradicate poverty mankind.

\section{Fatalistic view}

This view states that poverty is fate or destiny that must be passed by some people as a social phenomenon that cannot be avoided. This view is based on natural phenomenon created by Creator in tandem. On natural phenomena there day and night, earth and sky, mountains and valleys and so on. All these phenomena were created by the Creator is not in vain or without purpose, but rather for humans benefit, too. Similarly, in social phenomena such as the existence poor people and rich people, not something strange, and useless, but have a very significant meaning for human life to complement each other in meeting their individual needs. The rich have ability to excess funds for a brilliant brain, or professional skills that can give him a much higher income compared people around, but the rich do not have the time and energy to do manual or dirty labor. This is where the rich need the poor to supplement or help perform tasks that are also important to their lives, rich people are partnering with poor to meet their needs through the provision of a decent income for life. This is what is meant by the social phenomenon that pairs not collide. This view tends to let poverty go naturally, not to be eradicated completely.

\section{Convergence view between optimistic and fatalistic}

Another view is combination or synthesis of optimistic and fatalistic view. This view is not entirely optimistic and not fatalistic anyway. According with this view the poverty is human plight in life that must be dealt seriously by all parties, including the poor themselves, because poverty experienced by humans must be solved hardly with existing capabilities. If the man has a maximum effort, but has not managed to overcome poverty completely, then that must be accepted due to destiny, which were not many. These are obstacles to repair themselves. Perhaps they are they are physically weak, or weak mentally handicapped and helpless. Perhaps they also are men who do not care about the economic interests (worldly). They merely seek sustenance for life. Those poor people are a couple of rich people as part of an inevitable social phenomenon that will give its own wisdom for human life.

\subsection{Poverty Concept}

Poverty concept of National Development Planning Department is defined as a condition in which a person or group of people (men and women) that not fulfilled their basic rights to maintain and developing dignity life. Poverty definition moves from a rights-based approach that recognizes that poor people, both men and women, have rights equal basis with other community members. Poverty is no longer understood merely as the lack of economic, but also failure to fulfill basic rights and discrimination against a person or group of people. This basic right is rights of poor to life with dignity and rights to recognized in legislation. Basic rights generally that recognized, among others, are food, health, education, employment, housing, clean water, land, natural resources and environment, a sense of security and threat of violence and right to participate in social and political life.

Basic rights do not stand alone but influence each other influence so if one right cannot be fulfilled it will affect other rights fulfillment. With recognition the rights-based poverty concept, then poverty is seen as an event of rejection and non-fulfillment of rights. This concept gives the recognition that poor people are forced to undergo poverty and rights abuses that often demeaning dignity as human. Therefore, this concept emphasis on State obligation to respect, protect and fulfill the basic rights of poor people. Poverty is a complex phenomenon, multidimensional and cannot be easily seen and described with absolute number.

Poverty concept according with World Bank is a condition in which one lives with consumption of less than US\$ 2 per day (Todaro, 2004). Consumption is divided into two, namely: food and non-food. Expenditure consumption as food is a source of basic commodities, such as rice, oil and so on. Meanwhile, non-food expenditures are cloth and shelter. In this way, poverty is measured as level of per capita consumption below a certain standard that referred as poverty line. Those who are below the poverty line are categorized as poor. Poverty line is calculated by summing: (1) the cost to acquire a basket of food containing 2100 calories per capita per day, and (2) cost to acquire a basket of ingredients that not considered basic foods such as cloth, house, health, transportation, and education.

United Nations Development Program (UNDP) states that poverty concept is a condition where a person loses three main things (www. undp. org), namely: (1) life (more than 30 percent of poorest country tend to live less than forty years), (2) education (measured by the percentage of adult population is illiterate), and (3) economic provision by percentage of population who do not have access to health care and clean water plus the percentage of children under five year age that underweight. 
Central Statistics Agency (CSA), in attempt to explain or solving problem strategy, defines poverty as a condition where a person or group of people, men and women, not fulfilled their basic rights to maintain and develop a dignity life. Definition of poverty start from a rights-based approach that recognizes that poor people, both men and women, have rights equal basis with other community members. Poverty is not longer understood merely as the lack of economic, but also failure to fulfill basic rights and discrimination against a person or group people, men and women, to live with dignity.

Basic rights consist of rights that understood by the poor as right to be able to enjoy a dignity life and rights recognized in legislation. Basic rights generally recognized, among others, are requirement for food, health, education, employment, housing, clean water, land, natural resources and environment, safety feeling or threat of violence and right to participate in social life - politics, both for women and men. Basic rights do not stand alone but affect each other so not fulfill one right will affect to other rights fulfillment.

Based on rights -based poverty concept, then poverty is seen as an event of rejection and nonfulfillment of rights. This concept gives recognition that poor people are forced to undergo poverty and rights abuses that often demeaning dignity as a human. Therefore, this concept emphasis on state obligations to respect, protect and fulfill the basic rights of the poor.

According with Imam Syafii (al'um), indigent are people who did not have proceeds of income, or have assets and income, but less than half to meet their needs and their dependents. Poor people are those who have wealth or a decent income but not sufficient or less than the needs them self and their dependent (Gusfahmi, 2009). Indigent and poor people in Quran is sometimes referred separately, but more widely referred as poor. If called just poor, including poor in it. However, if called separately, indigent situation was even worse (QS: Albalad (90): 16) and (QS: Arrum (30): 38). Allah commands in the Qur'an of Attaubah: 60, firmly should concern to indigent then poor people. "Zakah expenditures are only for the poor and for the needy and for those employed to collect [zakah] and for bringing hearts together [for Islam] and for freeing captives [or slaves] and for those in debt and for the cause of Allah and for the [stranded] traveler - an obligation [imposed] by Allah. And Allah is Knowing and Wise".

\subsection{Forms of Poverty}

Cultural poverty is a form derived from poverty culture that owned by the poor, groups of people who are still static - traditional. Main actor who much studies cultural poverty was Oscar Lewis, 1966, in Ancok Jamaluddin, 1995. Lewis stated that poverty is a culture that happened due to suffering economy (Economic deprivation) for a long time. Mental attitude that not like to try, lazy, ignorant, spoiled by grace of nature, resigned and lazy work is part of poor culture. Furthermore, Ancok (1995) adds that people who grew up in a poverty culture have personality traits follows: feeling themselves useless, filled with despair, feeling inferior, very dependent on others. This poor people did not have a strong personality (ego strength), are less able to control yourself, easy impulsive and highly oriented to present with no thought of future. These properties makes the poor is difficult to plan for future.

Structural poverty is a form of poverty that directly related to behavior of people, both government and non-government organizations, and individual and groups, including all the rules and laws from human nature that perpetuate poverty. Actions which oppress and exploit poor people personal gain and greed of those who have power, and intelligence assets are partially and attitudes that maintain poverty. Similarly, rules and laws that do not favor poor are shackles for poor to remain poor. This is where the role of government and all state officials representing state to establish rules and policies that favor poor by the action on field honestly.

Mubyarto, 1995 revealed the inequality generally caused by two main things: (1) Market failure and (2) Political failure. Market failure directly related to market access failure toward poor people due to their low purchasing power of low wages and other revenue they receive as part of exploitation by more dominant people in terms of power and wealth. Political failure directly related to political will of all laws and policies that fail to raise dignity of poor people. Consistent with above opinion, Heru Nugroho (1995) revealed about poverty dimensions that poverty is not just dealing with economic problems of multi-dimensional but in reality dealing with non-economic issues (socio - cultural and political).

\section{Methods}

To reach research objective, it collected primary data with qualitative methods. In-depth interviews are done to informants to test validity of triangulation. This study was done in Southeast Sulawesi. Key informants are families poor who live in cities and villages. The complement informants are close relatives, neighbors or friends of informants. This is done in order to test triangulation validity of data sources. In addition, it also used study Focus Group Discussion (FGD) with peers and experts in qualitative research related to poverty. In order this research procedures is consistent with study purpose then the unit analysis used are:

1. Religious compliance of family head as a model for entire family. 
2. Morals that played by head of family to manage household and in conjunction with neighbors and surrounding community.

3. Social risk that experienced or potentially experienced by families in relation to fellow human beings.

4. Philosophy or life view that embraced by families undergo a life

This approach is a research method that refers to research procedures to produce qualitative data in the form of expressions, records, and their behavior observed. Therefore, researchers will focus on experience and life practice of poor families who live amidst society. In connection with issue and focus and purpose of research, then the other does not become main instrument, unless the executor or the researchers themselves. Other supporting instruments used are notebook, tape recorder as recording equipment, cameras and mobile phones.

Qualitative research data collection methods (human or researcher) are primary instrument. Data collection method in this study is: (1) observations, this technique is done to find objective phenomenal data where informant was not known by observed object. This technique is done in some places or situations, either planned or unplanned, but always according with needs of data relevant to research objectives, (2) interviews the informant conducted freely and deeply, and not scalable. Those interviewed were selected poor households according with research objectives, and (3) study documentation that carried out by taking photos of activities respondents. In addition, the documentation also conducted to collect notes, and text that related to research.

Data collection in this study will be carried out in 3 stages: First, data is collected by observing and interviewing several people (key figures) from poor families and key figures who knew a lot about poverty. Second, in-depth interviews are done to respondents who considered a source that has a lot more knowledge and deep understanding of various information required. This stage also is made further observations, by collecting various relevant texts. Finally, focus group discussions conducted to confirm deeply observations, interviews, and interpretation of information that has been achieved, before final conclusion made. Data/information collection strategies are used to facilitate data collection or accurate information acquisition. The Steps used is follows: First, informant goes at place and at most fun time (at leisure). Second, to know rightly informants address. Third, to visit each respondent home many times if information is still required as part of triangulation.

\section{Results And Discussion}

Based research objective, qualitative method with depth interviews with 4 people informant has achieved the following results.

1. Poor families with good quality (safe) are physically poor families, but with positive psychological (mental attitude of moral behavior spiritual). They have a clear life philosophy, simple, not consumptive, no miser, still want to share it with others, do not lazy (like work), not frustrated and still aspire to change fate with lawful efforts. They are also very honest and trustworthy. The informant has a good relationship with the Creator, worship regularly according with their religious believed. They have a good relationship with fellow human beings, peace within family home, and peace at outdoors with neighbors and community, even relationship with himself is always well maintained, for example by not damaging himself and his family. They also never against to Almighty God rules, government rules and customs (high values) in society. These criteria are achieved by informants of Muhammad by Ridwan family.

2. Poor families with low quality (not secure) are family that still has positive characteristics similar with good quality family but have also revealed certain deficiencies, such as: lack of harmony or internal fights within family or with neighbors and community. Or they have good internal relationship with family and community, but does not worship to Creator according with teachings and religious believed. In other words, a positive mental attitude is still possessed, but his spiritual character and behavior are no intact so that quality declined and included into groups with low quality. These criteria are achieved by informants 4 namely Sumaini.

3. Lowest poverty quality (least secure). This is the worst quality level because poor family almost does not have goodness to do. They mental attitude are resignation, frustration, dishonest, not trustworthy, and deviant. The poor physically, psychologically and also ignoring good relationship with Almighty God, destroy relationships with fellow human beings and do not maintain a good relationship with him. This informant destroys relationship with himself through various immoral actions as alcoholism, smoking, cheating and so on. This group also has a way of life by not keeping mandate, so nearly lost confidence from all men, except with his own group.

This conditions makes their families live as hostage with very bad judgment. This household becomes a mess and with no way out again. This is most severe of poor families and most priority to be empowered. If not empowered, they will meet physical needs (food, drink, clothing, housing and all other needs) with unlawful path like: steal, rob, and commit armed robbery, prostitution, and so on). Poor families at 2 and 3 positions are formal. 


\section{Research Implications}

Poor grouping that consists of: (1) poor families with good quality, (2) poor families with low quality and (3) poor families with lowest quality, empirically have implications on individual empowerment of each group related to how and where the most priority. Based on characteristics of each group, then priority is given to third group which live at the lowest quality. This group does not safe to neighbors and community at large. It is because this group is irrational; only think their short term needs especially primary needs. They are frustrated and very reluctant to work, so they have possibility to choose instant way. They do not care about the laws and rules. They only think about what to do in order to survive these days, life without a clear handle. Therefore they can steal, hold up, robbing, prostitution (for women) and do it without feel guilty. If they get stolen or robbery, they will become so reckless and use all money within a relatively short time, and they will steal and rob again in following days. As long as they have not been caught, they will continue to steal, cheat, rob and hold up without feeling guilty. That is why they must be prioritized to empowered before they harm others repeatedly that later ended after they were caught and improved in society empowerment agency that may not be successful, because they are already familiar with the chaotic life, with no heed the rules they are going through during this, so they repeat the act, after being released from institutions that foster them. It means empowerment should as fast as possible before they are forced to constructed in institution because caught.

Empowerment is mental and spiritual character that must be held professionally by training in selfcontrol effectively. With this empowerment, they will be measured of who entitled to further empowerment in form of economic empowerment with appropriate skills training based on the talent. This means that soul empowerment should be prioritized in the sense of thinking empowerment (economics). There is a possibility among them that not successful empowered mentally and spiritual, because God has closed his heart eyes and ears. What should be done is permanent donation in order go to street to commit a crime that is always latent within him, so he does not harm the other and themselves in their daily living.

Meanwhile those who categorized into poor with good quality (safe) can be empowered its economy if they want, but for those who do not want to do not need to bother with economic empowerment. They do not harm and will not harm anyone. Maybe they are the ones who feel happy in their poverty or elderly people who just want to take care of his worship to Creator or disabled persons mental no way to be empowered. They should be met their needs appropriately with a permanent benefit.

\section{Conclusions And Recommendations}

Groups of poor families in Southeast Sulawesi consists of: first, group with a good quality of poverty level (safe), poor people are not severely poor with characteristics such as: still has a good relationship with God Almighty, relationships with fellow human beings, both social and family levels, and relations with community at large. They have a positive view of life (living philosopher), not stingy, not wasteful, and not minded to perform acts that harm others even they still like to share and beneficial for others. Second, group with low poverty quality level (not secure) who have characteristics such as: relationship to God Almighty is not harmony/does not worship in accordance with law, relationships with fellow human beings already getting annoyed and view of life are not intact, but still trying to improve themselves and their families in future. In other words, this group of poor is not severe because there is goodness in thinking and doing.

Third, group with lowest poverty rate (least secure) with characteristics are: already frustrated, having a bad relationship with the God Almighty by ignoring orders and approaching the ban, had poor relationships with fellow human beings, internal family, and society (just hang out with others who have same vision), already suspicious because of their presence is suspected would steal, rob and commit armed robbery and other suspicious acts. Finally, according with poor group position then empowerment is not uniform even in ways that require very different, but professional will be able to improve quality of each group. In accordance with their own group, empowerments that become most priority are group 3 and group 2 .

The suggestions can be put forward is that that new research should use case studies, to determine what is visible, so it still needs to do more in the further to capture phenomenon visible or invisible. In addition, most priority in poverty empowerment is a group with a low quality (not safe) and group with lowest poverty quality.

\section{References}

[1] Al-Qur'an Digital, Program dan Terjemahannya.

[2] Al-Qur'an dan Terjemahannya, 1971. Khadim Al Haramain Assyarifain (Pelayanan Kedua Tanah Suci) kerajaan Arab Suadi.

[3] Ancok Djamaluddin, 1995. Pemanfaatan Organisasi Lokal Untuk Mengentaskan Kemiskinan dan Kesenjangan Ekonomi di Indonesia. Aditya Media Yogyakarta.

[4] Badan Pusat Statistik, 2010. Sulawesi Tenggara dalam angka. Kendari.

[5] Burhan Bungin, 2004. Metodologi Penelitian kualitatif. Surabaya.

[6] Gusfahmi, 2009. Rekonstruksi Praktek Zakat dan Pajak Untuk Menanggulangi Kemiskinan. Jurnal Pemikiran dan Gagasan Vol II.

[7] Hasan Aedy, 2004. Sistem Ekonomi Islam Dalam Menengani Kemiskinan; Sebuah Pendekatan Antara Akhlakuk Karimah Individual dan Peran Negara, Prosidang Simposim, Nasional Sistem Ekonomi Islam II, Malang PPB I, Unversitas Brawijaya. Malang.

[8] Hasan Aedy, 2005. Pengantar Ekonomi Islam, Unhalu Press. Kendari. 
[9] Hasan Aedy, 2006. Peranan Pemerintah dan Ulama dalam Pengelolaan Pajak, zakat dan Wakaf, Untuk Penanggulangan Kemiskinan dan Peningkatan Ekonomi Umat, Proceeding Of Internasional Seminar on Islamic Economics as Solution, Ikatan Ahli Ekonomi Indonesia, Medan, Sumatra Utara.

[10] Hasan Aedy, 2007. Indahnya Ekonomi Islam, Alfabeta. Bandung.

[11] Hasan Aedy, 2009. Kubangun Rumah Tanggaku Dengan Modal Akhlak Mulia, Alfabeta. Bandung.

[12] Hasan Aedy , 2010. Teori dan Aplikasi Ekonomi Pembangunan Dalam Perspektif Islam. Graha Ilmu. Solo.

[13] Hasan Aedy, 2010. Strategi dan Solusi Pengentasan Kemiskinan di Daerah Sulawesi Tenggara, Universitas Muhammadiyah Kendari, Kerjasama Dengan Badan Penelitian dan Pengembangan Propinsi Sulawesi Tenggara, Kendari.

[14] Mubyarto, 1995. Pembanguanan Ekonomi yang Berkeadilan, Dalam Buku Kemiskinan dan Kesenjangan Di Indonesia. Aditya Media. Yogyakarta.

[15] Todaro, 2004. Pembangunan Ekonomi di Dunia Ketiga. Erlangga Jakarta. 